The Canadian Mineralogist

Vol. 42, pp. 1065-1078 (2004)

\title{
NICKELOAN TOURMALINE FROM THE BEREZOVSKOE GOLD DEPOSIT, MIDDLE URALS, RUSSIA
}

\author{
Ivan A. BAKSHEEV ${ }^{\S}$ AND OLESYA E. KUDRYAVTSEVA \\ Geology Department, Lomonosov Moscow State University, Vorobiovy Gory, Moscow 119992, Russia
}

\begin{abstract}
Nickeloan tourmaline (up to 0.531 apfu $\mathrm{Ni}$ ) associated with nickeloan talc (0.511-0.582 apfu $\mathrm{Ni}$ ) or chromian muscovite is developed in magnesite-quartz veins hosted in ultramafic talc + magnesite \pm hematite \pm chromian muscovite hydrothermal alteration located in Uspenskaya Gorka, eastern flank of the Berezovskoe gold deposit, Middle Urals, Russia. The unusual Nirich composition of the silicates reflects the geochemical environment of formation. Tourmalines are represented by light and dark green needles in aggregates up to $2 \mathrm{~cm}$ in length. Crystals are characterized by a strong pleochroism, from colorless to green. Tourmaline cores associated with talc are magnesiofoitite with an elevated $\mathrm{Na}$ content $(0.436-0.452$ apfu $)$ and a $\mathrm{Mg} /\left(\mathrm{Fe}_{\text {tot }}+\mathrm{Mg}\right)$ value of 0.90 , or dravite [Na $\left.0.535-0.765 \mathrm{apfu}, \mathrm{Mg} /\left(\mathrm{Fe}_{\text {tot }}+\mathrm{Mg}\right) 0.87-0.88\right]$. In the magnesiofoitite, $\mathrm{Ni}$ and $\mathrm{Cr}$ contents range from 0.060 to $0.425 a p f u$, and from 0.214 to $0.249 a p f u$, respectively. In the dravitic cores, $\mathrm{Ni}$ and $\mathrm{Cr}$ contents range from 0.077 to $0.102 \mathrm{apfu}$ and from 0.000 to $0.272 \mathrm{apfu}$, respectively. Intermediate and rim zones are magnesiofoititic and dravitic [Na $0.443-$ $\left.0.938 \mathrm{apfu}, \mathrm{Mg} /\left(\mathrm{Fe}_{\text {tot }}+\mathrm{Mg}\right) 0.74-0.90\right]$. Ni and $\mathrm{Cr}$ contents in the same zones range from 0.020 to $0.531 \mathrm{apfu}$, and from 0.188 to 0.449 apfu. The distribution of the $\mathrm{Mg} /\left(\mathrm{Fe}_{\text {tot }}+\mathrm{Mg}\right)$ within single crystals is oscillatory. Partition coefficients for $\mathrm{Ni}$ and $\mathrm{Fe}_{\text {to }}$ between tourmaline and talc are 0.05 and 21.48 , respectively. Tourmaline associated with chromian muscovite can be classified as dravite (0.669-0.936 apfu $\mathrm{Na}$ ), with $\mathrm{Mg} /\left(\mathrm{Fe}_{\text {tot }}+\mathrm{Mg}\right.$ ) ranging from 0.76 to 0.89 . Some crystals are enriched in $\mathrm{Cr}$ (up to 1.564 apfu); $\mathrm{Ni}$ content ranges from 0.036 to $0.217 \mathrm{apfu}$. The Mössbauer study indicates that about half of the total $\mathrm{Fe}$ is $\mathrm{Fe}^{3+}$ in the tourmalines. Chromium and nickel are likely derived from altered ultramafic rocks.
\end{abstract}

Keywords: nickeloan tourmaline, nickeloan talc, chromian muscovite, ultramafic talc-carbonate alteration, Berezovskoe gold deposit, Urals, Russia.

\section{SOMMAIRE}

La tourmaline nickelifère (jusqu'à 0.531 apfu $\mathrm{Ni}$ ) associée au talc nickelifère $(0.511-0.582$ apfu $\mathrm{Ni}$ ) ou à la muscovite chromifère s'est développée dans des veines à magnésite + quartz recoupant des zones d'altération hydrothermales ultramafiques à talc + magnésite \pm hématite \pm muscovite chromifère situées à Uspenskaya Gorka, sur le flanc oriental du gisement aurifère de Berezovskoe, dans les Ourales moyennes, en Russie. La composition inhabituellement enrichie en Ni des silicates découle du milieu géochimique de formation. Les cristaux de tourmaline sont aciculaires et vert pâle à vert foncé, et les aggrégats atteignent une longueur de $2 \mathrm{~cm}$. Les cristaux sont fortement pléochrö̈ques, allant d'incolores à verts. Le coeur des cristaux associés au talc est fait de magnésiofoïtite avec une teneur élevée en $\mathrm{Na}\left(0.436-0.452\right.$ apfu) et une valeur $\mathrm{Mg} /\left(\mathrm{Fe}_{\text {tot }}+\mathrm{Mg}\right)$ de 0.90 , ou bien de dravite [Na 0.535-0.765 apfu, $\mathrm{Mg} /\left(\mathrm{Fe}_{\text {tot }}+\mathrm{Mg}\right)$ 0.87-0.88]. Dans la magnésiofoïtite, les teneurs en $\mathrm{Ni}$ et en $\mathrm{Cr}$ vont de 0.060 à $0.425 a p f u$, et de 0.214 à $0.249 a p f u$, respectivement. Dans la dravite, les teneurs en Ni et en Cr vont de 0.077 à $0.102 a p f u$ et de 0 à $0.272 a p f u$, respectivement. Les zones intermédiaires et de bordure sont magnésiofoïtitique et dravitique, respectivement [Na 0.443-0.938 apfu, $\mathrm{Mg} /\left(\mathrm{Fe}_{\text {tot }}+\mathrm{Mg}\right)$ 0.74-0.90]. Les teneurs en $\mathrm{Ni}$ et en $\mathrm{Cr}$ des mêmes zones vont de 0.020 à 0.531 apfu, et de 0.188 à $0.449 a p f u$. La distribution de $\mathrm{Mg} /\left(\mathrm{Fe}_{\text {tot }}+\mathrm{Mg}\right)$ à l'intérieur de monocristaux est oscillatoire. Les coefficients de distribution du Ni et du fer total entre tourmaline et talc sont 0.05 and 21.48 , respectivement. La tourmaline associée à la muscovite chromifère serait une dravite (0.669-0.936 apfu $\mathrm{Na})$, avec $\mathrm{Mg} /\left(\mathrm{Fe}_{\text {tot }}+\mathrm{Mg}\right)$ entre 0.76 et 0.89 . Dans certains cas, les cristaux sont enrichis en Cr (jusqu'à $1.564 a p f u$ ); les teneurs en Ni vont de 0.036 à $0.217 a p f u$. Une étude par spectroscopie de Mössbauer montre qu'environ la moitié du fer est à l'état ferrique dans les cristaux de tourmaline. Le chrome et le nickel seraient issus des roches ultramafiques altérées.

(Traduit par la Rédaction)

Mots-clés: tourmaline nickelifère, talc nickelifère, muscovite chromifère, altération ultramafique à talc-carbonate, gisement aurifère de Berezovskoe, Ourales, Russie.

$\S \quad$ E-mail address: baksheev@geol.msu.ru 


\section{INTRODUCTION}

Tourmaline is stable over a wide range of conditions from low-temperature hydrothermal alteration to highgrade and high-pressure metamorphic environments, and magmatic conditions. It occurs in caprocks and salt domes (Henry et al. 1999), in granite and granite pegmatite, in the volcanic-rock-hosted massive sulfide deposits (Taylor \& Slack 1984), in porphyry-copper deposits (King et al. 2000, Lynch \& Ortega 1997, Yavuz et al. 1999), in metamorphosed stratabound $\mathrm{Pb}-\mathrm{Zn}$ deposits (Slack 1996, Jiang et al. 1998), in medium-temperature hydrothermal gold (Robert \& Brown 1986, Anglin et al. 1996) and tin deposits (Kuzmin et al. 1979), in greisen deposits (London \& Manning 1995), and schist-type emerald deposits (Vlasov \& Kutukova 1960, Groat et al. 2002). Substitutions are thus widespread in tourmaline-group minerals, whose structural formula is $X Y_{3} Z_{6}\left[T_{6} \mathrm{O}_{18}\right]\left[\mathrm{BO}_{3}\right]_{3} V_{3} W$ (Hawthorne \& Henry 1999). Nickeloan tourmalines are relatively uncommon. Most are characterized by elevated chromium contents because of a relation to meta-ultramafic rocks (Jan et al. 1972, Challis et al. 1995, Michailidis et al. 1995). The highest Ni contents in tourmaline, however, have been described in metamorphosed karstbauxite in Greece (Henry \& Dutrow 2001). Nickel contents in the tourmaline in these rocks reach 3.53 wt.\% NiO.

The possibility of natural nickel-bearing tourmaline is consistent with experimental results. Gourdant \& Robert (1997) obtained a complete solid-solution from dravite to Ni-substituted dravite and from foitite to $\mathrm{Ni}$ substituted foitite. Structurally, Ni occupies the $Y$ octahedral sites. The ionic radii of $\mathrm{Ni}$ and $\mathrm{Mg}$ in octahedral coordination are similar, 0.69 and $0.72 \AA$, respectively (Qivx Inc. Integral Scientist Periodic Table 2003).

In this paper, we describe tourmaline with a relatively high $\mathrm{Ni}$ content. It occurs in quartz-carbonate veins located in ultramafic rocks with a propylitic-type hematite - talc - carbonate alteration in the Berezovskoe gold deposit, Middle Urals, Russia. It is the first find of tourmaline from altered ultramafic rocks with such high levels of $\mathrm{Ni}$, up to 3.96 wt.\% $\mathrm{NiO}$.

\section{Geological Setting, Wallrock Alteration AND ORE Mineralogy}

The mesothermal Berezovskoe gold deposit is located $10 \mathrm{~km}$ north of Ekaterinburg (Fig. 1). It occurs within the moderately eroded Berezovskii tectonic block, which is dominated by Lower Silurian volcanic and sedimentary rocks. Numerous stratiform and laccolith-shaped ultramafic bodies are included in the stratigraphic unit. The stratigraphic succession and the ultramafic bodies are cut by Lower Devonian gabbros. The succession is gently folded, dipping to 20 to $30^{\circ}$ to the west and northeast. The stratigraphic unit, ultramafic rocks and gabbros are weakly metamorphosed at greenschist-facies conditions. In the central part of the
Berezovskii block, the stratigraphic succession is intruded by adamellite of the Shartash pluton.

The numerous dikes of "plagiosyenite" porphyry, granodiorite porphyry, plagiogranite porphyry and lamprophyre cut both the stratigraphic unit and the pluton. The dikes extend several kilometers along strike. Most dikes are confined to the $\mathrm{N}-\mathrm{S}$ fractures that dominate within the gold field (Fig. 1). The age of the adamellite and the dikes, estimated with $\mathrm{K} / \mathrm{Ar}$ and $\mathrm{Rb} /$ $\mathrm{Sr}$ isotopic systems, is 315 to $355 \mathrm{Ma}$ (Sazonov et al. 2001), which corresponds to the Early Carboniferous. The adamellite and the dikes are not metamorphosed.

At least three hydrothermal metasomatic associations (altered wallrock) and related quartz veins are recognized within the Berezovskoe gold deposit. The associations are believed to be successive and related to dikes (Sazonov 1975, Spiridonov et al. 1998). These are barren propylite, tungsten-bearing "gumbeite" (see below) and gold-bearing "beresite-listwanite" (Borodaevsky \& Borodaevskaya 1947, Sazonov 1975, Spiridonov et al. 1998). The alteration assemblages were developed in all pre-existing rocks, including metamorphic rocks, adamellite, and dikes. The mineralogy of the assemblages is described below.

Propylitic alteration formed at the expense of silicic to mafic rocks includes chlorite, epidote, tourmaline, amphibole, albite, quartz, carbonate minerals, and hematite. Propylitically altered ultramafic rocks contain talc, magnesite, and hematite. Veins within the altered rock contain quartz, magnesite, talc, tourmaline and green $\mathrm{Cr}$-bearing muscovite. These altered rocks and veins are free of gold. The age of the association and related veins, estimated from the $\mathrm{Sm} / \mathrm{Nd}$ isotopic system on tourmaline, is $364 \pm 33 \mathrm{Ma}$ (Baksheev et al. 2002) and is close to that of the granitic rocks.

"Gumbeite" was first described by Korzhinsky (1955) within the Gumbeiskoe hydrothermal tungsten deposit, located about $40 \mathrm{~km}$ east of Magnitogorsk, Southern Urals, Russia. In the deposit, gumbeite is developed around scheelite-bearing veins; it contains quartz, microcline, carbonate minerals, and minor muscovite. Within the Berezovskoe deposit, gumbeite alteration, formed at the expense of silicic to mafic rocks, includes quartz, K-feldspar, calcite, dolomite, white mica, pyrite, and scheelite. Gumbeite-type alteration can also affect ultramafic rocks, which then contain talc, magnesite, phlogopite, and hematite. Gumbeite and related veins are free of gold. Detailed information on gumbeite, its genesis and associated mineralization is given in Spiridonov et al. (1998).

Wallrock alteration within the Berezovskoe gold deposit is dominated by the "beresite-listwanite" association. Beresite and listwanite were first described in the Berezovskoe deposit. Beresite, so named after the deposit, is formed at the expense of silicic rocks and contains quartz, white mica, dolomite, calcite, and pyrite. Listwanite (listvenite, listawaenite), after the Russian word listva (foliage), is green like foliage and 


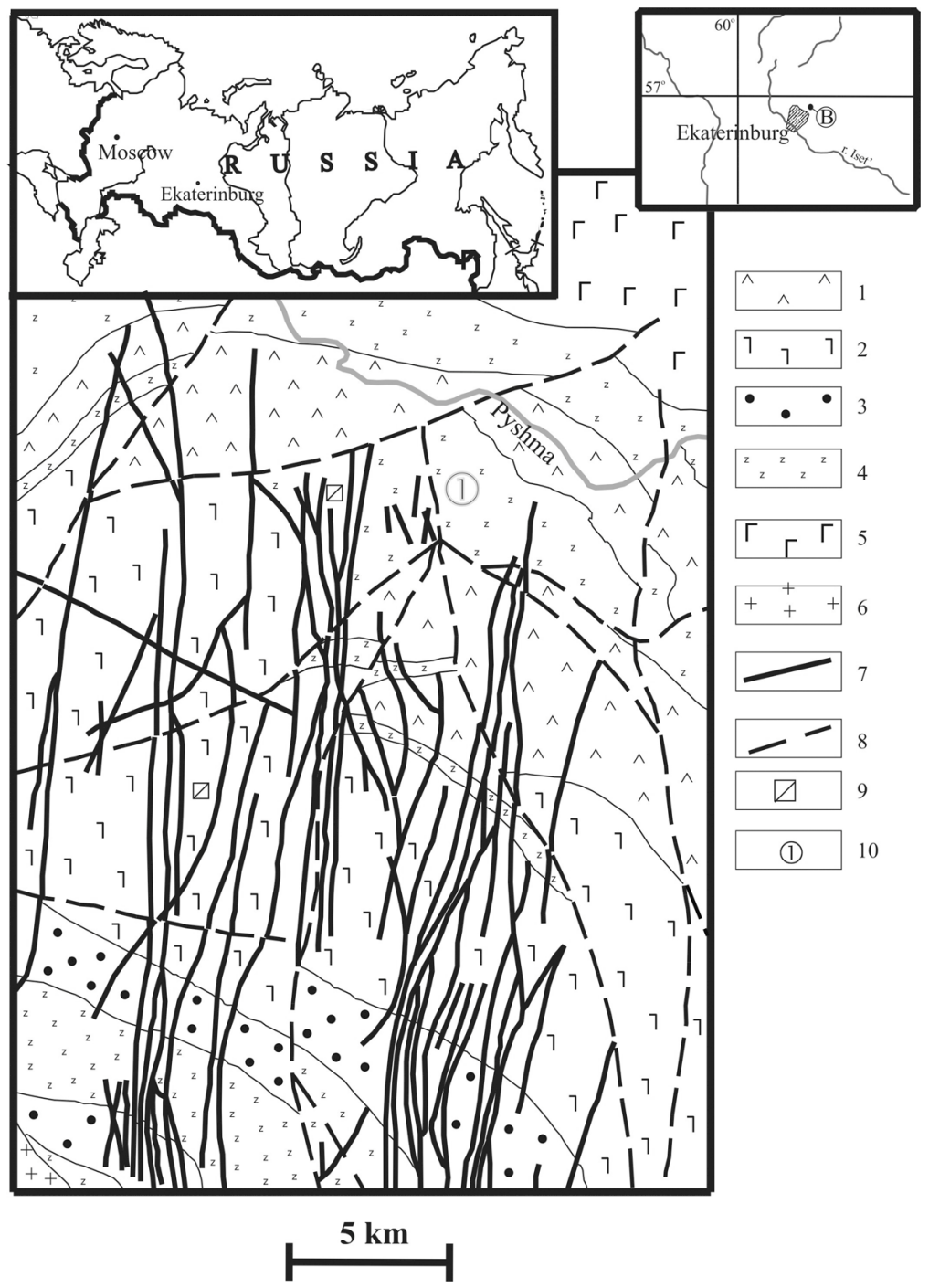

Fig. 1. Geological map of the Berezovskoe Au deposit, after Sustavov (1995) and Vikentieva (2000). 1 Early Silurian metadiabase, 2 Early Silurian metabasalt, 3 Early Silurian metasedymentary rocks, 4 Silurian to Devonian serpentinite, 5 Early Devonian gabbro, 6-7 Early Carboniferous granitic rocks, 6 adamellite of the Shartash massif, 7 granite porphyry dykes, 8 faults, 9 pits, 10 Uspenskaya Gorka. Inserts show the location of Ekaterinburg and the Berezovskoe gold deposit (B).

formed after serpentinized ultramafic rocks; it contains magnesite and chromian muscovite instead of calcite and white mica. Gold-bearing quartz veins are confined to the beresite-listwanite association. Coarse-grained quartz is the main gangue mineral. Carbonates are subordinate. Ore minerals, including pyrite, scheelite, galena, chalcopyrite, aikinite, tetrahedrite-tennantite and gold, fill interstices in quartz and in some cases form pockets in the veins. The fineness of gold is in the range 800-930. The age of the beresite-listwanite association and the associated gold-bearing quartz veins, as estimated from the $\mathrm{Sm} / \mathrm{Nd}$ isotopic system on scheelite, is $347 \pm 12 \mathrm{Ma}$ (Baksheev et al. 2002), which is close to the timing of the propylitic alteration and the emplacement of the granitic rocks. 


\section{Analytical TechniQues}

The chemical composition of tourmaline has been studied with a CAMEBAX SX-50 electron microprobe, N.N. Kononkova, analyst, of the Division of Mineralogy, Lomonosov Moscow State University. An accelerating potential of $15 \mathrm{kV}$ and current intensity of 30 $\mathrm{nA}$ were used with a beam diameter of $\sim 3 \mu \mathrm{m}$. PAP corrections were used for correction procedures. The following standards have been used: hornblende for $\mathrm{Si}$, $\mathrm{Al}, \mathrm{Ca}, \mathrm{Mg}, \mathrm{Fe}$, orthoclase for $\mathrm{K}$, albite for $\mathrm{Na}$, synthetic "fluorphlogopite" for $\mathrm{F}$, pyrophanite for $\mathrm{Mn}$ and $\mathrm{Ti}$, vanadinite for $\mathrm{V}, \mathrm{NiO}$ for $\mathrm{Ni}$, and $\mathrm{Cr}_{2} \mathrm{O}_{3}$ for $\mathrm{Cr}$.

The analysis of talc was made with a CAMSCAN scanning electron microscope equipped with a LINK 10000 energy-dispersion system (SEM-EDS), E.V. Guseva, analyst, Division of Petrology, Lomonosov Moscow State University. Operating conditions were: accelerating potential $15 \mathrm{kV}$, current intensity $1-6 \mathrm{nA}$, and beam diameter $3 \mu \mathrm{m}$. ZAF corrections were used for the correction procedures.

The tourmaline formulae were normalized on the basis of 15 cations exclusive of $\mathrm{Na}, \mathrm{Ca}$, and $\mathrm{K}$, i.e., assuming no vacancies at the tetrahedral or octahedral sites, and insignificant concentrations of Li (Henry et al. 1999). The Li content of tourmaline associated with nickeloan talc is estimated from flame spectrophotometry at $0.003 \mathrm{wt} . \% \mathrm{Li}_{2} \mathrm{O}$. In the case of tourmaline associated with green chromian muscovite, most of the $\mathrm{Li}$ probably is preferentially partitioned to mica (Henry \& Dutrow 1996). Charge-balance constraints were used to estimate the amounts of $\mathrm{OH}^{-}$and $\mathrm{O}^{2-}$ associated with the $V$ and $W$ anion sites in the structural formula, although there are likely significant uncertainties (Dutrow \& Henry 2000). We further assume that calculated $\mathrm{O}^{2-}$ (F below detection limit) is preferentially incorporated at the $W$ site (Hawthorne \& Henry 1999). The proportion of vacancies $(\square)$ was calculated using stoichiometric constraints by means of $1-(\mathrm{Na}-\mathrm{Ca}-\mathrm{K})$. These assumptions permit grouping of tourmaline in accordance with the classification proposed by Hawthorne \& Henry (1999). The amount of $\mathrm{B}_{2} \mathrm{O}_{3}$ was calculated from stoichiometric constraints. In the most representative results of the EMP analyses (see below), Fe is reported as both $\mathrm{Fe}^{2+}$ and $\mathrm{Fe}^{3+}$ with the assumption that roughly half the $\mathrm{Fe}$ is $\mathrm{Fe}^{3+}$. This assumption is based on the Mössbauer data. In several analyses, $\mathrm{Fe}$ is reported as $\mathrm{Fe}^{3+}$ in order to eliminate a charge deficiency at the $W$ site.

The Li content in tourmaline has been estimated by emission flame spectrophotometry with an AAC Varian-875 instrument in the Institute of Geology of Ore Deposits, Petrography, Mineralogy and Geochemistry (IGEM), Russian Academy of Science, G.E. Kalenchuk, analyst. The detection limit of the technique is $0.5 \mathrm{ppm}$.

A Mössbauer study was carried out in the Department of Chemistry of the Lomonosov Moscow State
University. A ${ }^{57} \mathrm{Fe}$ spectrum was recorded using a conventional Mössbauer spectrometer operating in constant acceleration mode with a ${ }^{57} \mathrm{Co}$ (in $\mathrm{Rh}$ ) source kept at room temperature. The isomer shift is referred to an $\alpha$ $\mathrm{Fe}$ absorber at $293 \mathrm{~K}$. The spectrum was analyzed using standard computer techniques.

The composition of talc was normalized on the basis of seven cations $(\mathrm{Si}+\mathrm{Mg})$, in accordance with the suggestion of Borneman-Starynkevich (1964). Distribution coefficients $\left(K_{D}\right)$ for $\mathrm{Ni}$ and total $\mathrm{Fe}$ between nickeloan tourmaline and nickeloan talc were calculated as the ratio of the cations.

\section{Results}

Nickeloan tourmaline assocciated with nickeloan talc or green Cr-bearing muscovite occurs within magnesite-quartz veinlets and veins in Uspenskaya Gorka located in the Eastern flank of the Berezovskoe gold deposit (Fig. 1). The unusual compositions of the silicates reflects a Ni- and $\mathrm{Cr}$-rich geochemical environment of the mineralization, because the veins are hosted in hematite - talc - carbonate alteration formed at the expense of the ultramafic rocks. The thickness of the veinlets and veins range from $5 \mathrm{~cm}$ to $3 \mathrm{~m}$.

The nickeloan tourmaline + nickeloan talc association

Tourmaline associated with nickeloan talc occurs in magnesite-quartz vein hosted in hematite - talc - magnesite alteration. The visible extent of the vein is about $20 \mathrm{~m}$, and it is up to $3 \mathrm{~m}$ in width. Quartz is developed in at least two generations. Milky quartz I constitutes most of the vein, whereas transparent quartz II fills small pockets. A fluid-inclusion study of milky quartz I from the quartz-magnesite vein indicates that it formed at a

\begin{tabular}{|c|c|c|c|c|c|}
\hline & 1 & 2 & 3 & 4 & 5 \\
\hline $\begin{array}{l}\mathrm{SiO}_{2} \text { wt.\% } \\
\mathrm{Al}_{2} \mathrm{O}_{3} \\
\mathrm{MgO} \\
\mathrm{FeO}_{\text {tot }} \\
\mathrm{NiO} \\
\mathrm{H}_{2} \mathrm{O}^{*}\end{array}$ & $\begin{array}{r}60.58 \\
0.00 \\
23.23 \\
1.49 \\
10.41 \\
4.69\end{array}$ & $\begin{array}{r}60.38 \\
0.00 \\
23.54 \\
1.43 \\
10.28 \\
4.62\end{array}$ & $\begin{array}{r}60.31 \\
0.00 \\
23.11 \\
1.53 \\
10.71 \\
4.63\end{array}$ & $\begin{array}{r}59.95 \\
0.27 \\
23.13 \\
1.43 \\
10.82 \\
4.57\end{array}$ & $\begin{array}{r}60.38 \\
0.23 \\
23.81 \\
1.65 \\
9.55 \\
4.62\end{array}$ \\
\hline Total & 100.40 & 100.25 & 100.29 & 100.17 & 100.24 \\
\hline $\begin{array}{l}\text { Si apfu } \\
\mathrm{Al} \\
\mathrm{Mg} \\
\mathrm{Fe}_{\text {etot }} \\
\mathrm{Ni}^{\mathrm{i}} \\
\mathrm{O}^{2-} \\
\mathrm{OH}^{-}\end{array}$ & $\begin{array}{l}4.044 \\
0.000 \\
2.313 \\
0.083 \\
0.559 \\
0.089 \\
1.911\end{array}$ & $\begin{array}{l}4.027 \\
0.000 \\
2.341 \\
0.080 \\
0.552 \\
0.055 \\
1.945\end{array}$ & $\begin{array}{l}4.034 \\
0.000 \\
2.304 \\
0.086 \\
0.576 \\
0.067 \\
1.933\end{array}$ & $\begin{array}{l}4.010 \\
0.021 \\
2.307 \\
0.080 \\
0.582 \\
0.040 \\
1.960\end{array}$ & $\begin{array}{l}4.017 \\
0.018 \\
2.362 \\
0.092 \\
0.511 \\
0.052 \\
1.948\end{array}$ \\
\hline $\mathrm{Mg} /\left(\mathrm{Fe}_{\mathrm{rot}}+\mathrm{Mg}\right)$ & 0.97 & 0.97 & 0.96 & 0.97 & 0.96 \\
\hline
\end{tabular}

* The amount of $\mathrm{H}_{2} \mathrm{O}$ is calculated from stoichiometry. Columns 1-5: different small plates. The structural formula is calculated on the basis of a total of seven cations. 
temperature ranging from 290 to $330^{\circ} \mathrm{C}$ (average $310^{\circ} \mathrm{C}$ : Baksheev et al. 2001).

Magnesite crystals attain $5 \mathrm{~cm}$ across. These crystals, however, are strongly weathered. Magnesite and talc form intergrowths with quartz I, an indication that the minerals grew simultaneously.

Nickeloan talc is megascopally bright green in color and forms pockets up to $5 \mathrm{~cm}$ diameter (Fig. 2). Sustavov (1995) reported that talc occurs very close to the contact between the magnesite-quartz vein and host alteration. The Ni content ranges from 9.55 to 10.71 wt. $\% \mathrm{NiO}$, and the $\mathrm{Mg} /\left(\mathrm{Fe}_{\text {tot }}+\mathrm{Mg}\right)$ value is high, 0.96 or 0.97 (Table 1). The mineral contains $\mathrm{Al}$ (up to 0.27 wt. $\% \mathrm{Al}_{2} \mathrm{O}_{3}$ ). Sustavov (1995) reported 12.0 wt.\% NiO in the talc.

Tourmaline constitutes about $5 \%$ of the vein's volume. It is intergrown with quartz I, indicating their simultaneous crystallization. Quartz II contains inclusions of the tourmaline. Tourmaline develops isolated light and dark green needles up to $1 \mathrm{~cm}$ long or as aggregates of tourmaline needles (Fig. 3). Crystals are pleochroic from colorless to green.

Because all analyzed crystals of tourmaline are $\mathrm{Ca}$ poor, the optimal plot to distinguish species to a first approximation is $\mathrm{Mg} /\left(\mathrm{Mg}+\mathrm{Fe}_{\text {tot }}\right)$ versus $X$-site vacancy / (Na $+X$-site vacancy) (Fig. 4). This diagram does not distinguish among the $\mathrm{OH}-, \mathrm{F}-$ and $\mathrm{O}-$ bearing species. However, $\mathrm{F}$ contents are below detection levels for all analyzed grains, and therefore the $W$ site is dominated by $\mathrm{O}^{2-}$ or $\mathrm{OH}^{-}$. Consequently, the magnesiofoitite and dravite fields could also be considered "oxy-magnesiofoitite" and "oxy-dravite" fields, respectively. In general, the tourmaline compositions are characterized by

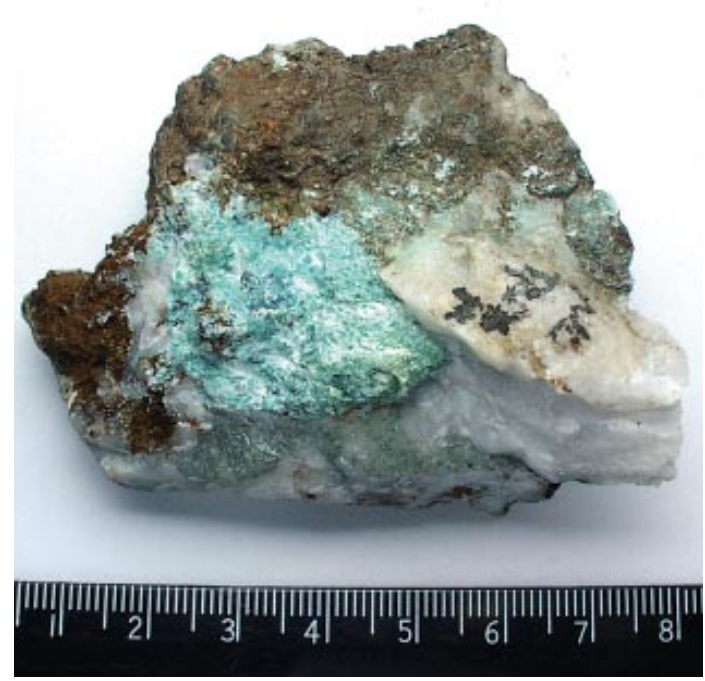

FIG. 2. Pocket of green nickeloan talc in magnesite-quartz vein, Uspenskaya gorka. Scale in $\mathrm{cm}$.

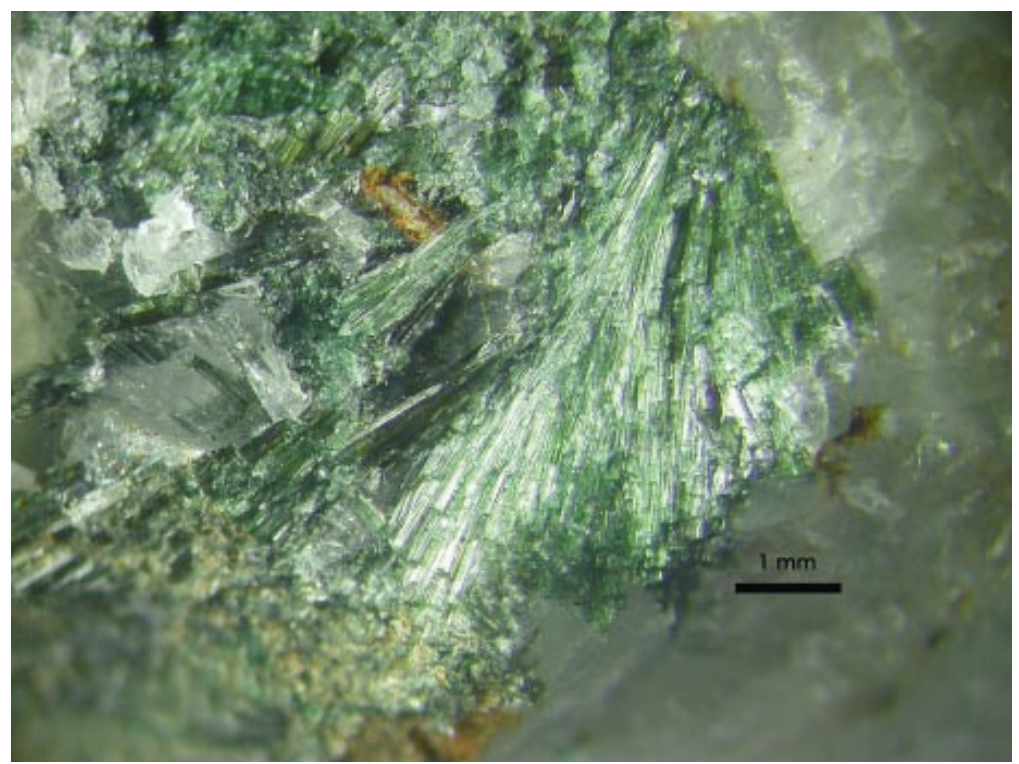

FIG. 3. Intergrowths of light green nickeloan tourmaline and quartz, Uspenskaya gorka. Scale bar: $1 \mathrm{~mm}$. 
TABLE 2. COMPOSITION OF TOURMALINE ASSOCIATED WITH NICKELOAN TALC, FROM THE BEREZOVSKOE GOLD DEPOSIT, MIDDLE URALS, RUSSIA

\begin{tabular}{|c|c|c|c|c|c|c|c|c|c|c|c|}
\hline & 1 core & $2 \mathrm{int}$ & 3 inter & $4 \mathrm{rim}$ & 5 core & $6 \mathrm{rim}$ & 7 core & 8 int & $9 \mathrm{rim}$ & $10 \mathrm{rim}$ & $11 \mathrm{int}$ \\
\hline $\begin{array}{l}\mathrm{B}_{2} \mathrm{O}_{3} \mathrm{wt} . \% \\
\mathrm{SiO}_{2} \\
\mathrm{TiO}_{2} \\
\mathrm{Cr}_{2} \mathrm{O}_{3} \\
\mathrm{~V}_{2} \mathrm{O}_{3} \\
\mathrm{Al}_{2} \mathrm{O}_{3} \\
\mathrm{NiO} \\
\mathrm{FeO}_{\text {lotal }} \\
\mathrm{MnO} \mathrm{MgO} \\
\mathrm{CaO} \\
\mathrm{K}_{2} \mathrm{O} \\
\mathrm{Na}_{2} \mathrm{O}\end{array}$ & $\begin{array}{r}10.96 \\
37.68 \\
0.03 \\
1.71 \\
0.07 \\
33.14 \\
0.47 \\
1.95 \\
0.00 \\
9.71 \\
0.03 \\
0.00 \\
1.42\end{array}$ & $\begin{array}{r}10.73 \\
37.01 \\
0.00 \\
1.72 \\
0.09 \\
31.99 \\
0.53 \\
2.15 \\
0.02 \\
9.53 \\
0.05 \\
0.03 \\
1.41\end{array}$ & $\begin{array}{r}10.93 \\
37.39 \\
0.00 \\
1.96 \\
0.11 \\
35.18 \\
0.58 \\
2.15 \\
0.02 \\
7.79 \\
0.00 \\
0.00 \\
2.52\end{array}$ & $\begin{array}{r}10.94 \\
36.99 \\
0.30 \\
2.76 \\
0.00 \\
32.15 \\
2.77 \\
2.87 \\
0.00 \\
8.38 \\
0.00 \\
0.02 \\
2.68\end{array}$ & $\begin{array}{r}10.65 \\
37.27 \\
0.00 \\
1.93 \\
0.10 \\
31.21 \\
3.24 \\
1.71 \\
0.00 \\
8.21 \\
0.00 \\
0.00 \\
1.43\end{array}$ & $\begin{array}{r}10.42 \\
37.06 \\
0.14 \\
2.94 \\
0.00 \\
28.68 \\
3.96 \\
1.63 \\
0.00 \\
8.12 \\
0.00 \\
0.00 \\
1.82\end{array}$ & $\begin{array}{r}10.71 \\
36.06 \\
0.05 \\
2.14 \\
0.10 \\
30.71 \\
0.78 \\
2.67 \\
0.00 \\
10.41 \\
0.04 \\
0.02 \\
2.43\end{array}$ & $\begin{array}{r}10.50 \\
34.68 \\
0.15 \\
2.85 \\
0.12 \\
30.25 \\
0.40 \\
4.51 \\
0.00 \\
9.21 \\
0.08 \\
0.02 \\
2.84\end{array}$ & $\begin{array}{r}10.67 \\
35.58 \\
0.11 \\
2.54 \\
0.02 \\
34.03 \\
1.14 \\
1.95 \\
0.00 \\
7.90 \\
0.03 \\
0.04 \\
2.92\end{array}$ & $\begin{array}{r}10.72 \\
36.02 \\
0.17 \\
1.71 \\
0.12 \\
33.74 \\
1.62 \\
2.38 \\
0.04 \\
7.96 \\
0.08 \\
0.02 \\
2.73\end{array}$ & $\begin{array}{r}10.58 \\
36.14 \\
0.31 \\
3.24 \\
0.10 \\
30.27 \\
0.29 \\
4.26 \\
0.03 \\
8.63 \\
0.08 \\
0.04 \\
2.79\end{array}$ \\
\hline Total & 97.17 & 95.26 & 98.63 & 99.86 & 95.75 & 94.77 & 96.12 & 95.61 & 96.93 & 97.31 & 96.76 \\
\hline $\begin{array}{l}\text { B apfu } \\
\mathrm{Si} \\
{ }^{T} \mathrm{Al}\end{array}$ & $\begin{array}{l}3.000 \\
5.971 \\
0.029\end{array}$ & $\begin{array}{l}3.000 \\
5.995 \\
0.005\end{array}$ & $\begin{array}{l}3.000 \\
5.942 \\
0.058\end{array}$ & $\begin{array}{l}3.000 \\
5.877 \\
0.123\end{array}$ & $\begin{array}{l}3.000 \\
6.081 \\
0.000\end{array}$ & $\begin{array}{l}3.000 \\
6.180 \\
0.000\end{array}$ & $\begin{array}{l}3.000 \\
5.851 \\
0.149\end{array}$ & $\begin{array}{l}3.000 \\
5.740 \\
0.260\end{array}$ & $\begin{array}{l}3.000 \\
5.793 \\
0.207\end{array}$ & $\begin{array}{l}3.000 \\
5.837 \\
0.163\end{array}$ & $\begin{array}{l}3.000 \\
5.932 \\
0.068\end{array}$ \\
\hline${ }^{z} \mathrm{Al}$ & 6.000 & 6.000 & 6.000 & 5.897 & 6.000 & 5.637 & 5.724 & 5.642 & 6.000 & 6.000 & 5.789 \\
\hline $\begin{array}{l}{ }^{y} \mathrm{Al} \\
\mathrm{Mg} \\
\mathrm{Fe}^{3+} \\
\mathrm{Fe}^{2+} \\
\mathrm{Cr} \\
\mathrm{Ni} \\
\mathrm{Ti} \\
\mathrm{V} \\
\mathrm{Mn}\end{array}$ & $\begin{array}{l}0.161 \\
2.294 \\
0.258 \\
0.000 \\
0.214 \\
0.060 \\
0.004 \\
0.009 \\
0.000\end{array}$ & $\begin{array}{l}0.103 \\
2.302 \\
0.291 \\
0.000 \\
0.220 \\
0.069 \\
0.000 \\
0.012 \\
0.003\end{array}$ & $\begin{array}{l}0.531 \\
1.846 \\
0.143 \\
0.143 \\
0.246 \\
0.074 \\
0.000 \\
0.014 \\
0.003\end{array}$ & $\begin{array}{l}0.000 \\
1.985 \\
0.191 \\
0.190 \\
0.347 \\
0.354 \\
0.036 \\
0.000 \\
0.000\end{array}$ & $\begin{array}{l}0.002 \\
1.997 \\
0.233 \\
0.000 \\
0.249 \\
0.425 \\
0.000 \\
0.013 \\
0.000\end{array}$ & $\begin{array}{l}0.000 \\
2.019 \\
0.114 \\
0.113 \\
0.388 \\
0.531 \\
0.018 \\
0.000 \\
0.000\end{array}$ & $\begin{array}{l}0.000 \\
2.518 \\
0.362 \\
0.000 \\
0.275 \\
0.102 \\
0.006 \\
0.013 \\
0.000\end{array}$ & $\begin{array}{l}0.000 \\
2.273 \\
0.312 \\
0.312 \\
0.327 \\
0.053 \\
0.019 \\
0.016 \\
0.000\end{array}$ & $\begin{array}{l}0.324 \\
1.918 \\
0.133 \\
0.133 \\
0.327 \\
0.149 \\
0.013 \\
0.003 \\
0.000\end{array}$ & $\begin{array}{l}0.282 \\
1.923 \\
0.162 \\
0.161 \\
0.219 \\
0.211 \\
0.021 \\
0.016 \\
0.005\end{array}$ & $\begin{array}{l}0.000 \\
2.112 \\
0.292 \\
0.292 \\
0.421 \\
0.038 \\
0.038 \\
0.013 \\
0.004\end{array}$ \\
\hline$Y$ total & 3.000 & 3.000 & 3.000 & 3.103 & 2.919 & 3.183 & 3.276 & 2.946 & 3.000 & 3.000 & 3.210 \\
\hline $\begin{array}{l}\mathrm{Na} \\
{ }^{x} \square \\
\mathrm{Ca} \\
\mathrm{K}\end{array}$ & $\begin{array}{l}0.436 \\
0.559 \\
0.005 \\
0.000\end{array}$ & $\begin{array}{l}0.443 \\
0.542 \\
0.009 \\
0.006\end{array}$ & $\begin{array}{l}0.777 \\
0.223 \\
0.000 \\
0.000\end{array}$ & $\begin{array}{l}0.826 \\
0.170 \\
0.000 \\
0.004\end{array}$ & $\begin{array}{l}0.452 \\
0.548 \\
0.000 \\
0.000\end{array}$ & $\begin{array}{l}0.588 \\
0.412 \\
0.000 \\
0.000\end{array}$ & $\begin{array}{l}0.765 \\
0.224 \\
0.007 \\
0.004\end{array}$ & $\begin{array}{l}0.911 \\
0.062 \\
0.014 \\
0.004\end{array}$ & $\begin{array}{l}0.922 \\
0.065 \\
0.005 \\
0.008\end{array}$ & $\begin{array}{l}0.856 \\
0.126 \\
0.014 \\
0.004\end{array}$ & $\begin{array}{l}0.888 \\
0.090 \\
0.014 \\
0.008\end{array}$ \\
\hline$X$ total & 1.000 & 1.000 & 1.000 & 1.000 & 1.000 & 1.000 & 1.000 & 1.000 & 1.000 & 1.000 & 1.000 \\
\hline${ }^{\prime} \mathrm{OH}^{-}$ & 3.000 & 3.000 & 3.000 & 3.000 & 3.000 & 3.000 & 3.000 & 3.000 & 3.000 & 3.000 & 3.000 \\
\hline $\begin{array}{l}{ }^{w} \mathrm{OH}^{-} \\
{ }^{w} \mathrm{O}^{2-}\end{array}$ & $\begin{array}{l}0.933 \\
0.067\end{array}$ & $\begin{array}{l}0.912 \\
0.088\end{array}$ & $\begin{array}{l}0.347 \\
0.653\end{array}$ & $\begin{array}{l}0.786 \\
0.214\end{array}$ & $\begin{array}{l}0.889 \\
0.111\end{array}$ & $\begin{array}{l}0.877 \\
0.123\end{array}$ & $\begin{array}{l}0.980 \\
0.020\end{array}$ & $\begin{array}{l}0.624 \\
0.376\end{array}$ & $\begin{array}{l}0.454 \\
0.546\end{array}$ & $\begin{array}{l}0.552 \\
0.446\end{array}$ & $\begin{array}{l}0.498 \\
0.502\end{array}$ \\
\hline$W$ total & 1.000 & 1.000 & 1.000 & 1.000 & 1.000 & 1.000 & 1.000 & 1.000 & 1.000 & 1.000 & 1.000 \\
\hline $\begin{array}{l}m g \\
c a\end{array}$ & $\begin{array}{l}0.90 \\
0.01\end{array}$ & $\begin{array}{l}0.89 \\
0.02\end{array}$ & $\begin{array}{l}0.87 \\
0.00\end{array}$ & $\begin{array}{l}0.84 \\
0.00\end{array}$ & $\begin{array}{l}0.90 \\
0.00\end{array}$ & $\begin{array}{l}0.90 \\
0.00\end{array}$ & $\begin{array}{l}0.87 \\
0.01\end{array}$ & $\begin{array}{l}0.78 \\
0.02\end{array}$ & $\begin{array}{l}0.88 \\
0.01\end{array}$ & $\begin{array}{l}0.86 \\
0.02\end{array}$ & $\begin{array}{l}0.78 \\
0.02\end{array}$ \\
\hline
\end{tabular}

Atomic proportions, expressed in atoms per formula unit (apfu), based on 15 cations except $(\mathrm{Na}+\mathrm{Ca}$ $+\mathrm{K}$ ). Note: Single crystals are 1-4, 5-6, 7-9, 10-22; int: intermediate zone of crystal.

their values of $\mathrm{Ca} /(\mathrm{Ca}+\mathrm{Na})$ and $\mathrm{Mg} /\left(\mathrm{Fe}_{\text {tot }}+\mathrm{Mg}\right)$, ranging from 0 to 0.02 and from 0.74 to 0.90 , respectively (Table 2). The Mössbauer data indicate that about half iron in the tourmaline is $\mathrm{Fe}^{3+}\left(\mathrm{Fe}^{3+} / \mathrm{Fe}_{\text {tot }}=0.53\right)$. The $\mathrm{Li}$ content in the tourmaline, estimated from flame spectrophotometry, is 0.003 wt. $\% \mathrm{Li}_{2} \mathrm{O}$.

On the basis of compositional characteristics of the core, the tourmaline can be divided into two groups. The first group includes magnesiofoitite cores with elevated Na content $(0.436-0.452$ apfu $)$ that are characterized by variable Ni contents, ranging from 0.060 to 0.425 apfu (Table 2, anal. 1 and 5). Intermediate zones and rims are dravitic with $\mathrm{Na}$ and $\mathrm{Ni}$ contents ranging from 0.588 to $0.826 \mathrm{apfu}$ and from 0.074 to $0.531 \mathrm{apfu}$, respectively (Table 2, anal. 3-4, 6). The second group includes dravitic core compositions with $\mathrm{Na}$ content ranging from 0.535 to 0.765 apfu (Table 2, anal. 7 and 16). The Ni content in the cores ranges from 0.077 to $0.102 \mathrm{apfu}$ and is close to that in intermediate zones and rims. We have studied in detail one optically and chemically complicated zoned crystal of tourmaline from the second group (Fig. 5, Table 2, anal. 10-22). The Na content in the core of the crystal is less $(0.535 a p f u)$ than that in intermediate zones (0.742-0.938 apfu) and rims (0.888- 
TABLE 2 (cont'd). COMPOSITION OF TOURMALINE ASSOCIATED WITH NICKELOAN TALC FROM THE BEREZOVSKOE GOLD DEPOSIT, MIDDLE URALS, RUSSIA

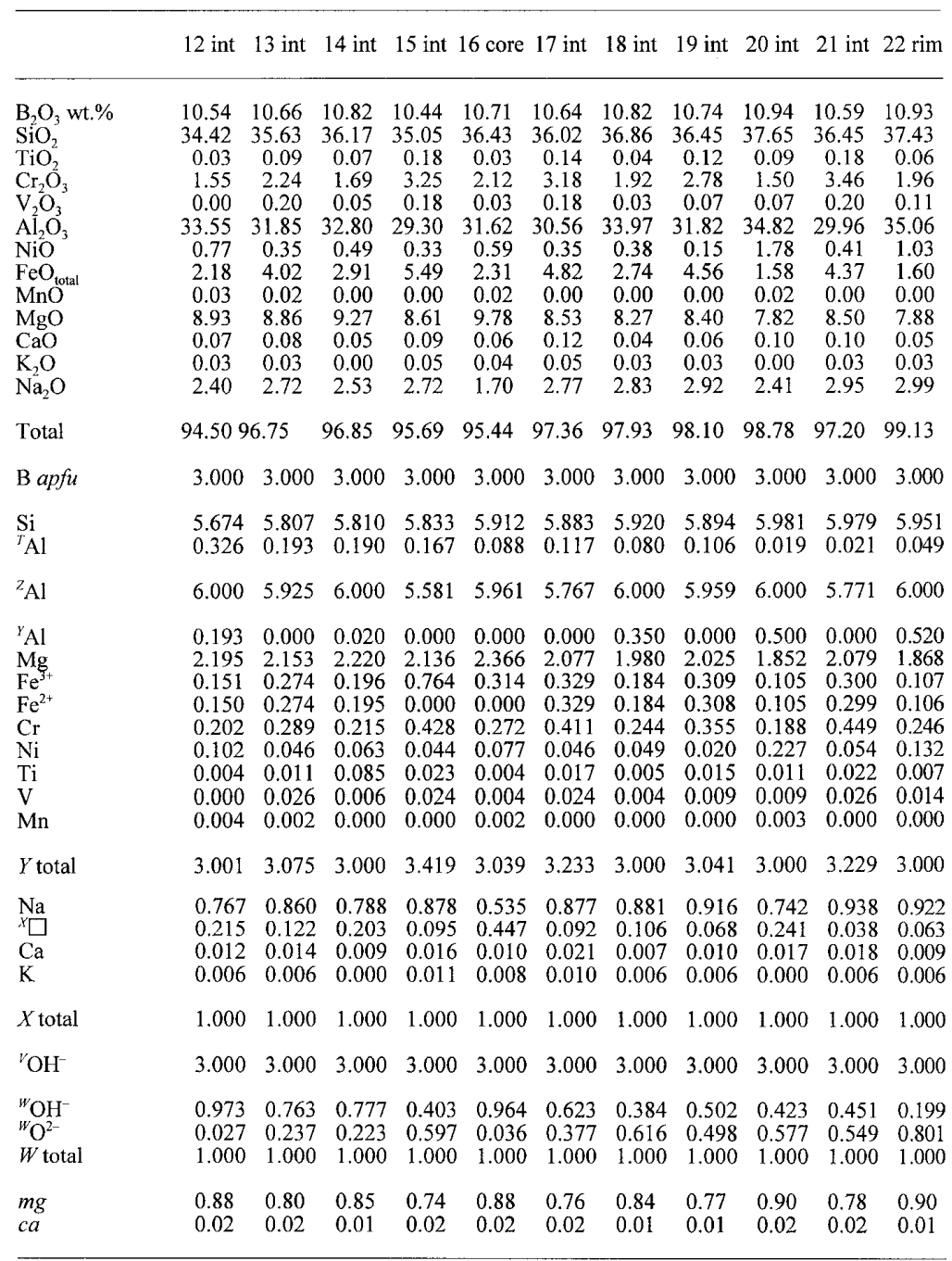

$\mathrm{F}$ is below detection limit. $\mathrm{B}_{2} \mathrm{O}_{3}$ calculated by stoichiometry. $\mathrm{Fe}^{3+}$ in columns $1,2,5,7,15$, and 16 calculated assuming that $\mathrm{Fe}$ total is $\mathrm{Fe}^{3+} . m g$ is the $\mathrm{Mg} /\left(\mathrm{Fe}_{\text {total }}+\mathrm{Mg}\right)$ value, $c a$ is the $\mathrm{Ca} /(\mathrm{Ca}+\mathrm{Na})$ value.

0.922 apfu) (Fig. 6a). The $\mathrm{Mg} /\left(\mathrm{Fe}_{\text {tot }}+\mathrm{Mg}\right.$ ) value and the Ni content are distributed in an oscillatory and irregular fashion (Figs. 6b, c).

\section{The tourmaline + mica association}

This association occurs in thin quartz veinlets of up to $5 \mathrm{~cm}$ thick among quartz-magnesite altered rock containing a small amount of Cr-bearing muscovite. Mica forms small, bright green flakes and pockets both in the altered rock and quartz veinlets. Qualitative electronmicroprobe analyses indicate that the light mica is $\mathrm{Cr}$ - bearing muscovite. Magnesite is represented by yellowbrown crystals up to $2 \mathrm{~cm}$ in size. Tourmaline is represented by dark green crystals up to $1 \mathrm{~cm}$ long. It is intergrown with quartz. Figure 4 shows that the tourmaline occupies the dravite and "oxy-dravite" field. Tourmaline cores are characterized by different $\mathrm{Na}$ content ranging from 0.669 to $0.936 a p f u$; the $\mathrm{Mg} /\left(\mathrm{Fe}_{\text {tot }}+\right.$ $\mathrm{Mg}$ ) value ranges from 0.76 to 0.87 (Table 3, anal. 1-3, $5,7)$. The $\mathrm{Na}$ content and the $\mathrm{Mg} /\left(\mathrm{Fe}_{\text {tot }}+\mathrm{Mg}\right)$ value in the tourmaline rims range from 0.790 to $0.906 a p f u$ and from 0.77 to 0.89 , respectively (Table 3 , anal. $4,6,8$ ). The tourmaline is richer in $\mathrm{Cr}$ (up to $1.564 a p f u$ ) than 


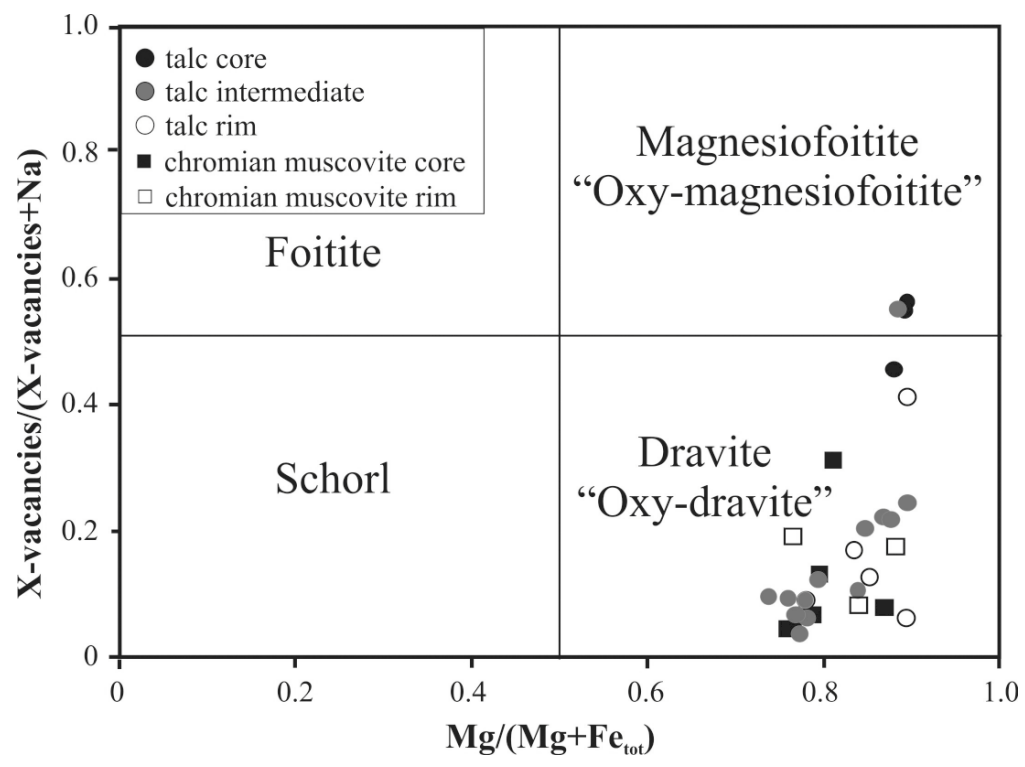

FIG. 4. Compositions of Berezovskoe tourmaline plotted in terms of $X$ vacancy and $\mathrm{Mg} /$ $\left(\mathrm{Fe}_{\mathrm{tot}}+\mathrm{Mg}\right)$. End-member compositions of schorl, foitite, magnesiofoitite, "oxymagnesiofoitite", dravite, and "oxy-dravite" plot at the corners of the diagram.

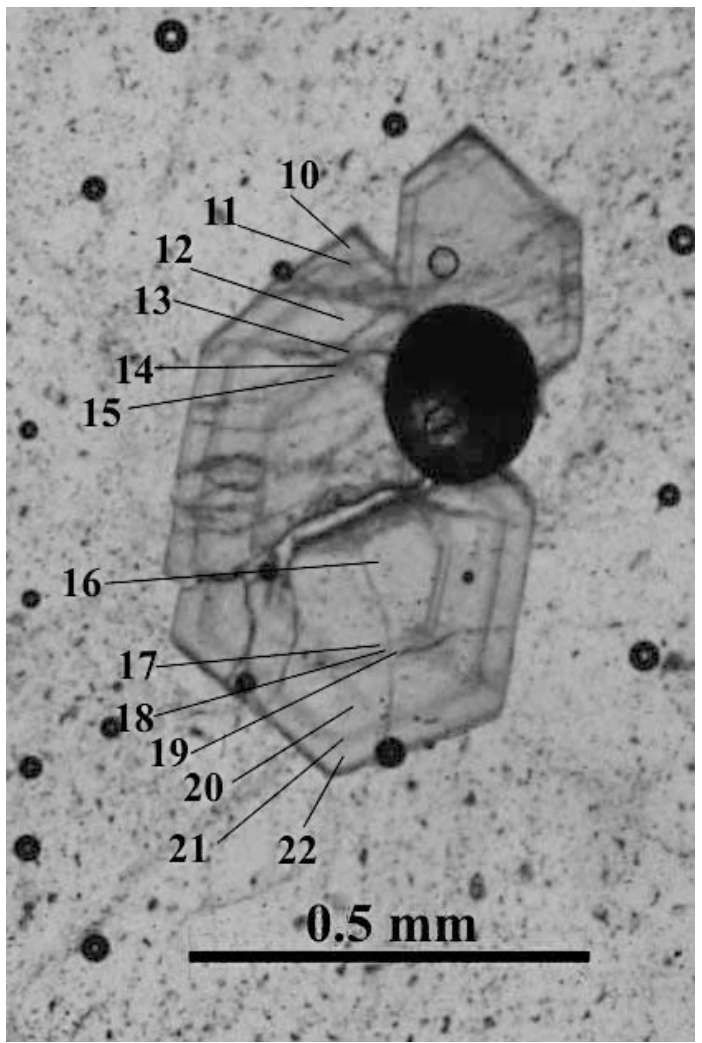

that associated with nickeloan talc. The $\mathrm{Ni}$ content $(0.036-0.217 a p f u)$ and the $\mathrm{Ca} /(\mathrm{Ca}+\mathrm{Na})$ value $(0-0.04)$ are comparable to those in tourmaline associated with nickeloan talc. Likewise, the Mössbauer data indicate that about half the iron in the tourmaline is $\mathrm{Fe}^{3+}\left(\mathrm{Fe}^{3+} /\right.$ $\mathrm{Fe}_{\text {tot }}=0.53$ ).

\section{DisCUSSION}

Tourmaline crystals from the nickeloan talc - magnesite - quartz and chromian muscovite - magnesite quartz veins and veinlets hosted in ultramafic hematite - talc - magnesite alteration are characterized by a high $\mathrm{Mg} /\left(\mathrm{Fe}_{\text {tot }}+\mathrm{Mg}\right)$ value and, within separate crystals, by high $\mathrm{Ni}$ (up to 0.531 apfu) and $\mathrm{Cr}$ (1.564 apfu) contents. Enrichment in Ni and $\mathrm{Cr}$ probably is caused by the replacement of $\mathrm{Ni}$ - and $\mathrm{Cr}$-bearing minerals in the precursor ultramafic rocks.

Henry \& Dutrow (2001) reported a high Ni content (up to 0.36 apfu) but low $\mathrm{Cr}$ (up to $0.06 \mathrm{apfu}$ ) in dravite from metamorphosed karstbauxite. A negative correlation between $(\mathrm{Mg}+\mathrm{Mn}+\mathrm{Ni}+\mathrm{Co}+\mathrm{Zn})$ and $\mathrm{Fe}$ has

FIG. 5. Photomicrograph of optically zoned crystal of nickeloan tourmaline. Numbers correspond to analyzed points listed in Table 2 and Figure 6. 
been shown for the tourmaline in their suite, indicating solid solution involving these elements. In general, there is no such correlation for nickeloan tourmaline from Berezovskoe (Fig. 7), probably because iron is present as both $\mathrm{Fe}^{2+}$ and $\mathrm{Fe}^{3+}$. A strong pleochroism and the Mössbauer data are consistent with this interpretation.

Distribution coefficients for $\mathrm{Ni}$ and $\mathrm{Fe}_{\text {tot }}$ between nickeloan tourmaline and nickeloan talc are 0.05 and 21.48 , respectively, indicating preferential incorporation of $\mathrm{Ni}$ in talc and $\mathrm{Fe}$ in tourmaline. Figure 8 provides a good illustration for this partition.

$\mathrm{An}(\mathrm{Al}+\mathrm{Cr})$ versus $\left(\mathrm{Mg}+\mathrm{Ni}+\mathrm{Fe}_{\text {tot }}\right)$ diagram (Fig. 9) shows that the data are spread in a linear array (reference line has a slope of -0.89 , correlation coefficient -0.93). The minor deviation of the linear fit from a slope of -1 suggests that other substitutions contribute to the dispersion of the data. The exchange vectors $(\square \mathrm{Al})(\mathrm{NaR})_{-1}$ and $(\mathrm{AlO})\left[\mathrm{R}(\mathrm{OH})_{-1}\right.$, where $\mathrm{R}$ is sum of $\mathrm{Mg}, \mathrm{Fe}_{\text {tot }}$ and $\mathrm{Ni}$, and $\mathrm{Fe}_{\text {tot }} \mathrm{Al}_{-1}$ are almost collinear with

TABLE 3. COMPOSITIONOF TOURMALINE FROM CHROMIANMUSCOVITE - CARBONATE - QUARTZ VEIN FROM THE BEREZOVSKOE GOLD DEPOSIT, MIDDLE URALS, RUSSIA

1 core 2 core 3 core 4 rim 5 core 6 rim $\quad 7$ core 8 rim

\begin{tabular}{|c|c|c|c|c|c|c|c|c|}
\hline $\mathrm{B}_{2} \mathrm{O}_{3}$ wt. $\%$ & 10.54 & 10.53 & 10.52 & 10.49 & 10.35 & 10.53 & 10.56 & 10.34 \\
\hline $\mathrm{SiO}_{2}^{3}$ & 35.43 & 35.71 & 36.26 & 36.46 & 35.68 & 37.10 & 35.64 & 36.05 \\
\hline $\mathrm{TiO}_{2}^{2}$ & 0.14 & 0.06 & 0.13 & 0.09 & 0.36 & 0.09 & 0.11 & 0.13 \\
\hline $\mathrm{Cr}_{2} \mathrm{O}_{3}$ & 3.61 & 3.50 & 5.85 & 2.31 & 5.69 & 5.07 & 5.73 & 11.77 \\
\hline${ }_{2} \mathrm{O}_{3}$ & 0.25 & 0.11 & 0.00 & 0.10 & 0.18 & 0.10 & 0.13 & 0.00 \\
\hline $\mathrm{I}_{2} \mathrm{O}_{3}$ & 29.06 & 27.30 & 30.35 & 29.01 & 27.39 & 28.00 & 31.26 & 26.32 \\
\hline io & 0.27 & 0.39 & 1.63 & 0.29 & 0.39 & 1.04 & 0.90 & 1.22 \\
\hline & 5.11 & 4.76 & 2.83 & 4.90 & 16 & 2.96 & 03 & 1.62 \\
\hline & 9.19 & 10.62 & & & & & & 7.01 \\
\hline 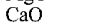 & 0.04 & 0.02 & 0.15 & 0.08 & 0.08 & 0.06 & 0.03 & 0.04 \\
\hline & & & & & & & & \\
\hline $\mathrm{Na}_{2} \mathrm{O}_{2}$ & 2.93 & 2.67 & 2.09 & .46 & 2.82 & 2.83 & 2.87 & 2.51 \\
\hline Total & 96.62 & 95.72 & 96.79 & 95.35 & 95.60 & 96.71 & 97.02 & 97.01 \\
\hline В apfu & 3.000 & 3.000 & 3.000 & 3.000 & 3.000 & 3.000 & 3.000 & 3.000 \\
\hline $\mathrm{Si}$ & 5.838 & 5.892 & 5.987 & 6.039 & 5.990 & 6.132 & 5.862 & 6.058 \\
\hline${ }^{7} \mathrm{Al}$ & .162 & 0.108 & 0.013 & 0.000 & 0.010 & 0.000 & 0.138 & 0.000 \\
\hline${ }^{z} \mathrm{Al}$ & 5.482 & 5.201 & 5.894 & 5.664 & 5.411 & 5.447 & 5.923 & 5.213 \\
\hline${ }^{\gamma} \mathrm{Al}$ & 0.000 & 0.000 & 0.000 & 0.000 & 0.000 & 0.000 & 0.000 & 0.000 \\
\hline $\mathrm{Mg}$ & & 2.612 & 1.718 & 2 & 28 & & & 1.756 \\
\hline & & 0.657 & 0.15 & & & & & \\
\hline $\mathrm{Fe}^{2}$ & & 0.000 & 0.195 & 0.3 & 0.292 & 0.2 & & \\
\hline $\mathrm{Cr}$ & 0 & 0.457 & 0.764 & 93 & .755 & 62 & & 1.564 \\
\hline $\mathrm{Ni}$ & & 0.0 & 0.2 & & & & & 0.165 \\
\hline $\mathrm{Ti}$ & & .007 & 0.016 & & & & & \\
\hline $\mathrm{V}$ & 0.033 & 0.015 & 0.000 & 0.013 & 0.024 & 0.013 & 0.017 & 0.000 \\
\hline$Y$ total & 3.518 & 3.800 & 3.106 & 3.297 & 3.589 & 3.430 & 3.077 & 3.729 \\
\hline $\mathrm{Na}$ & & 0.854 & 0.669 & 0.790 & 0.918 & 0.906 & & \\
\hline$\square$ & & 0.1 & 0 & & & & & \\
\hline $\mathrm{Ca}$ & & 0.004 & 0.027 & 0.0 & 0.014 & & & 0.007 \\
\hline $\mathrm{K}$ & 0.011 & 0.011 & 0.000 & 0.008 & 0.000 & 0.000 & 0.000 & 0.000 \\
\hline$X$ total & 1.000 & 1.000 & 1.000 & 1.000 & 1.000 & 1.000 & 1.000 & 1.000 \\
\hline${ }^{\mathrm{O}} \mathrm{OH}^{-}$ & & 3.000 & 3.000 & 3.000 & 3.000 & & & \\
\hline${ }^{{ }^{\mathrm{OI}}}$ & & 0.88 & 0.404 & 0.7 & 0.4 & 0. & 0.3 & 0.129 \\
\hline & & 0.111 & 0.596 & 0.246 & 0.508 & 0.553 & 0.640 & 0.871 \\
\hline$W$ total & 1.000 & 1.000 & 1.000 & 1.000 & 1.000 & 1.000 & 1.000 & 1.000 \\
\hline$m g$ & & 0.80 & 0.81 & & 0.7 & 0.8 & 0.8 & 0.89 \\
\hline$c a$ & 0.01 & 0.00 & 0.04 & 0.02 & 0.02 & 0.01 & 0.01 & 0.01 \\
\hline
\end{tabular}

Note: $\mathrm{F}$ and $\mathrm{Mn}$ are below detection limit. $\mathrm{B}_{2} \mathrm{O}_{3}$ calculated by stoichiometry. Single crystals are $1,2,3-4,5-6,7-8 . \mathrm{Fe}^{3+}$ in analyses 2 calculated assuming that $\mathrm{Fe}$ total is this reference line and could result in offsets parallel to it. We can correct for the $\mathrm{Al}$ associated with $X$-site vacancies in a coupled substitution by plotting $(\mathrm{Al}+\mathrm{Cr}-$ $X$-site vacancies) versus $\left(\mathrm{Mg}+\mathrm{Ni}+\mathrm{Fe}_{\text {tot }}+X\right.$-site vacancies), for which the correlation coefficient is -0.95 (Fig. 10). This results in a plot in which dravite and magnesiofoitite are superimposed at the same point, as are "oxy-dravite" and "oxy-magnesiofoitite". The data are distributed such that there are several points near the "oxy" end-members. If it is assumed that half of the $\mathrm{Fe}$ is $\mathrm{Fe}^{3+}$, as presented in Tables 2 and 3 (except where such an assumption would lead to a charge deficiency), this relationship can be explored on an $\left(\mathrm{Al}+\mathrm{Cr}+\mathrm{Fe}^{3+}\right.$ $-X$-site vacancies) versus $\left(\mathrm{Mg}+\mathrm{Ni}+\mathrm{Fe}^{2+}+X\right.$-site vacancies) diagram (correlation coefficient -0.94 ) (Fig. 11). In this case, the data are generally distributed between the dravite-magnesiofoitite and "oxy-dravite oxy-magnesiofoitite". This finding is consistent with our earlier determination that roughly half of the tourmaline compositions determined should be classed as "oxydravite".

The composition of nickeloan tourmalines from Berezovskoe is affected by two factors: the composition of the host rocks and the nature of mineralizing fluid. Altered rocks can be the source for $\mathrm{Mg}, \mathrm{Ni}$, and $\mathrm{Cr}$, whereas $\mathrm{Si}, \mathrm{Al}$, and $\mathrm{B}$ have been introduced by hydrothermal fluids. Different $\mathrm{Ni}$ and $\mathrm{Cr}$ contents within separate crystals and zones could be explained by replacement of $\mathrm{Ni}$ - and $\mathrm{Cr}$-bearing minerals of the source rock. Association with nickeloan talc, elevated Ni content and the high $\mathrm{Fe}^{3+} / \mathrm{Fe}_{\text {tot }}$ ratio in the tourmaline indicate a high $f\left(\mathrm{O}_{2}\right)$ of the fluid.

Magnesiofoitite has been found in various geological environments, including granitic pegmatites and magnesian skarns hosted in magnesite marble in the Kuhilal deposit, Tajikistan (Rossovsky 1963), hydrothermally altered volcanic rocks (Hawthorne et al. 1999), tourmaline-quartz veins in the Baraboo quartzite, Wisconsin, USA (Medaris et al. 2003). In the first and the third cases, tourmaline probably crystallized under sodium-deficient conditions, and in the second, at the low values of $\mathrm{pH}$ that are characteristic of alteration of the volcanic suites.

Some tourmaline grains in the Berezovskoe suite are assumed to start crystallizing in an environment of $\mathrm{Na}$ deficiency, and then $a_{\mathrm{Na}}$ increased. Oscillatory zoning of the Berezovskoe tourmaline indicates that the history of tourmaline crystallization is complex.

\section{Conclusions}

The discovery of tourmaline with very high $\mathrm{Ni}$ content (up to $0.53 \mathrm{apfu}$ ) from a magnesite-quartz vein hosted in ultramafic hematite - talc - carbonate alteration is novel. Chromium and nickel in tourmaline are likely derived from primary minerals in the ultramafic rocks. Tourmaline crystallized from a moderate-temperature fluid characterized by high $f\left(\mathrm{O}_{2}\right)$. The history 

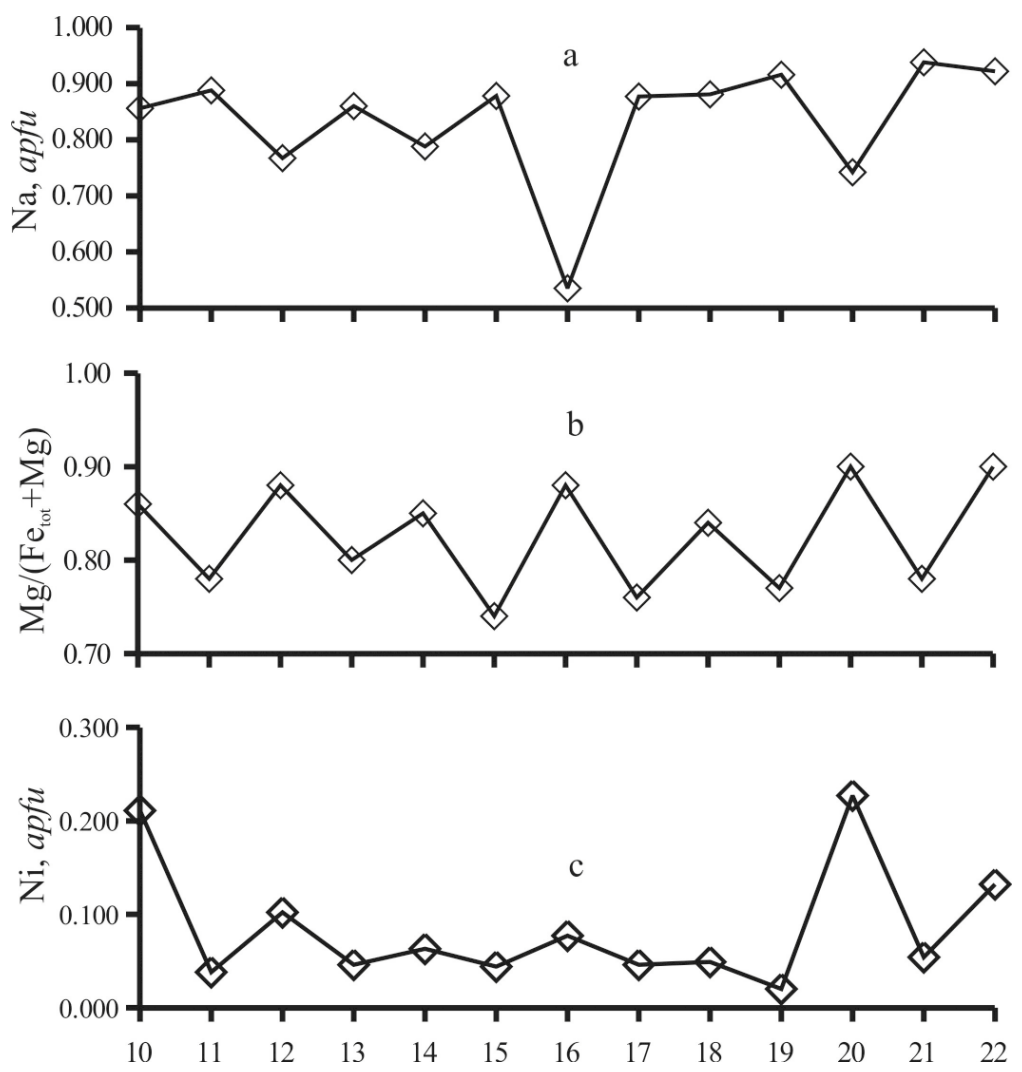

FIG. 6. Varieties of the $\mathrm{Mg} /\left(\mathrm{Fe}_{\text {tot }}+\mathrm{Mg}\right.$ ) ratio (a), $\mathrm{Ni}(a p f u)$ (b) and $\mathrm{Na}(a p f u)$ (c) in the points shown in Figure 4.

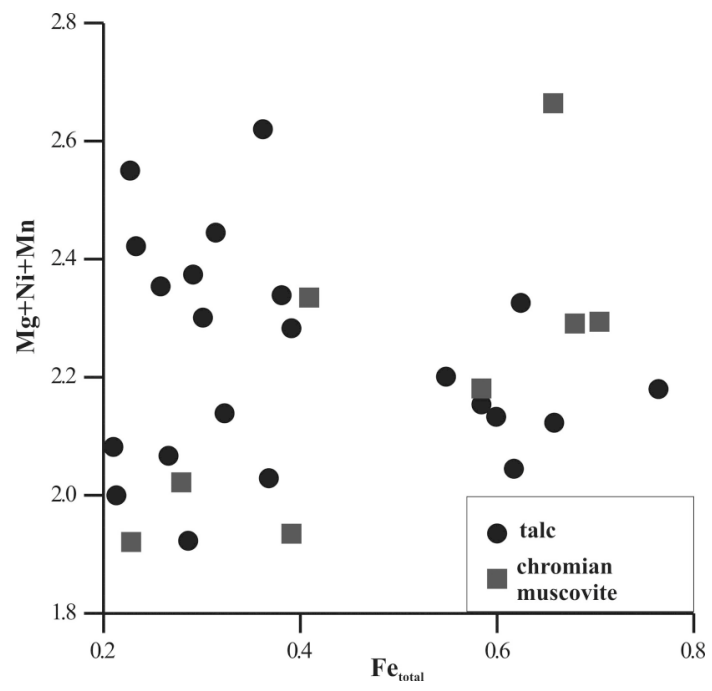

FIG. 7. Fe (total) versus $(\mathrm{Mg}+\mathrm{Mn}+\mathrm{Ni})$ diagram showing data on tourmaline data from Berezovskoe. of tourmaline crystallization is probably complex because of oscillating compositions of the fluid.

\section{ACKNOWLEDGEMENTS}

The authors acknowledge the constructive comments of Darrell J. Henry and John M. Hughes and the editorial revisions of Robert F. Martin, which have significantly improved this paper. We are also grateful to Igor V. Pekov for his invaluable comments.

\section{REFERENCES}

Anglin, C.D., Jonasson, I.R. \& FrankLin, J.M. (1996): Sm$\mathrm{Nd}$ dating of scheelite and tourmaline: implications for the genesis of Archaean gold deposits, Val d'Or, Canada. Econ. Geol. 91, 1372-1383.

Baksheev, I.A., Prokofyev, V.Yu., Ustinov, V.I. \& Kudryavtseva, O.E. (2001): Conditions of tourmaline mineralization and its relation to the gold ore at the Berezovskoye Au deposit, central Urals. ECROFI XVI (Porto), Abstr., 27-29. 


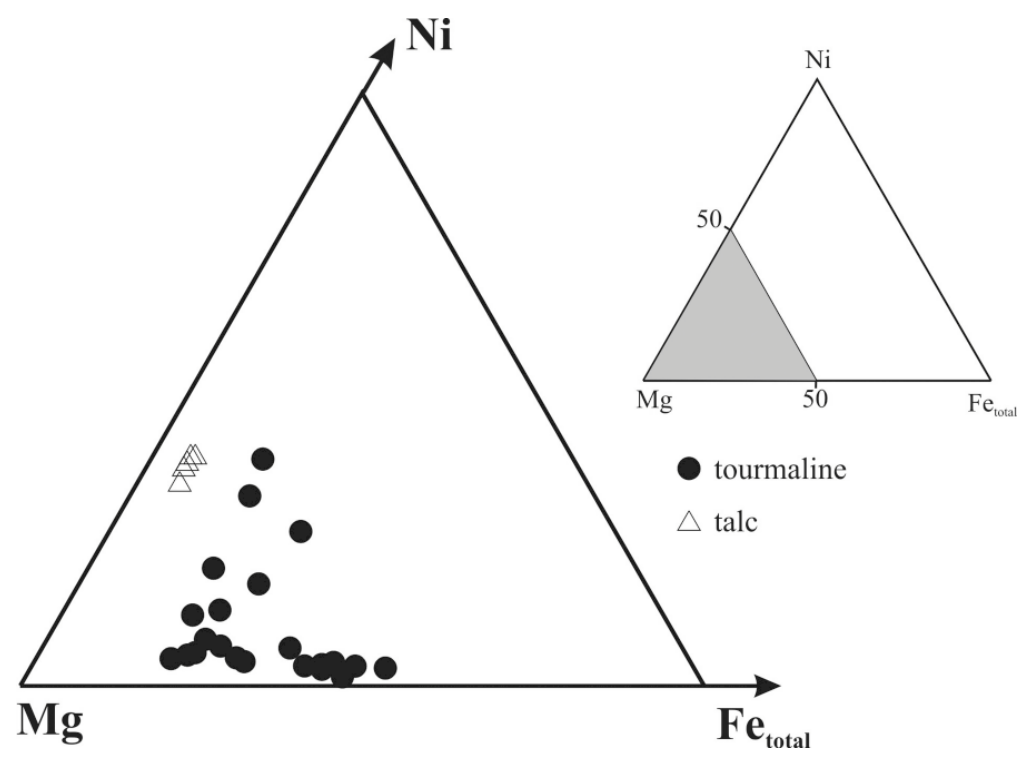

FIG. 8. Triangular diagram in terms of $\mathrm{Mg}-\mathrm{Fe}-\mathrm{Ni}$ for nickeloan talc and tourmaline, illustrating partition of $\mathrm{Fe}$ and $\mathrm{Ni}$ between these minerals.

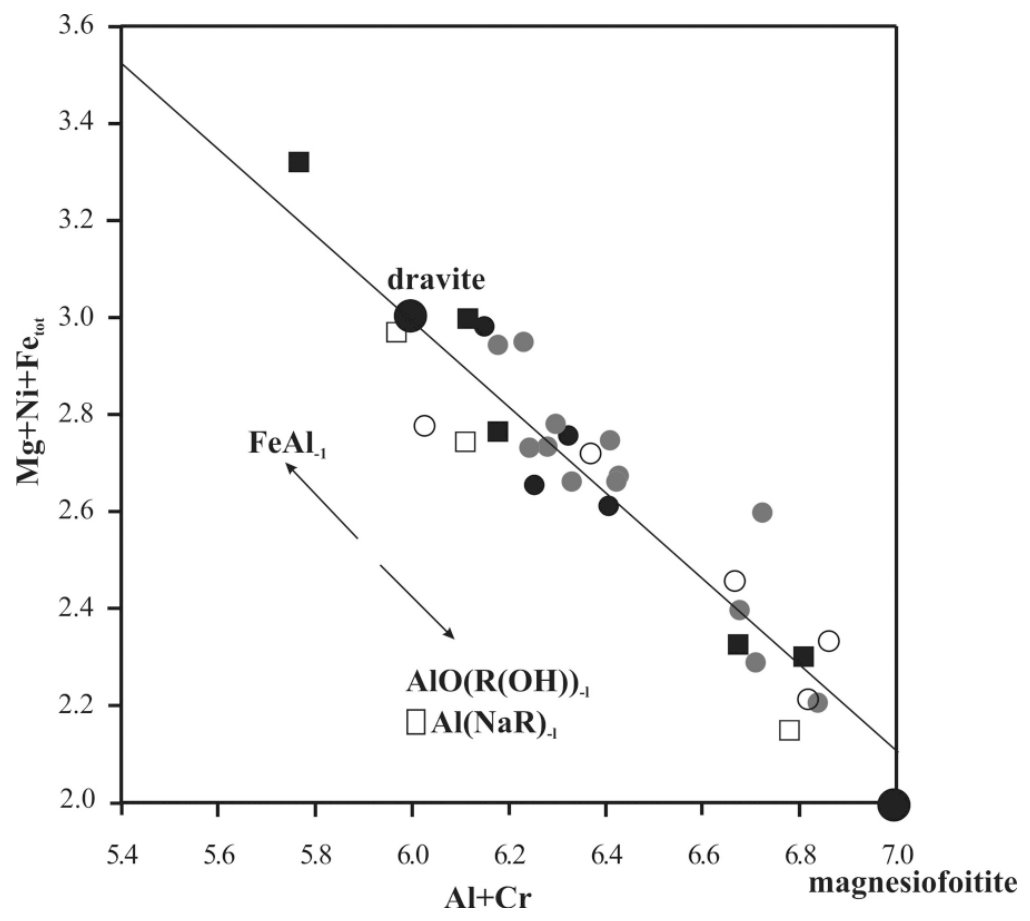

FIG. 9. $\mathrm{Al}+\mathrm{Cr}$ versus $\mathrm{R}\left(\mathrm{Mg}+\mathrm{Ni}+\mathrm{Fe}_{\text {tot }}\right)$ diagram for tourmaline from the nickeloan talc and chromian muscovite associations. $R$ represents the sum of $\mathrm{Mg}+\mathrm{Ni}+\mathrm{Fe}$ (total). The solid line represents a linear least-squares regression through the tourmaline data from both associations, $\left(\mathrm{Mg}+\mathrm{Ni}+\mathrm{Fe}_{\mathrm{tot}}\right)=-0.890(\mathrm{Al}+\mathrm{Cr})+8.345$. The directions of several selected exchange-vectors are given for reference. The locations of end-member dravite and magnesiofoitite are shown by the large filled circles. See Figure 4 for legend. 


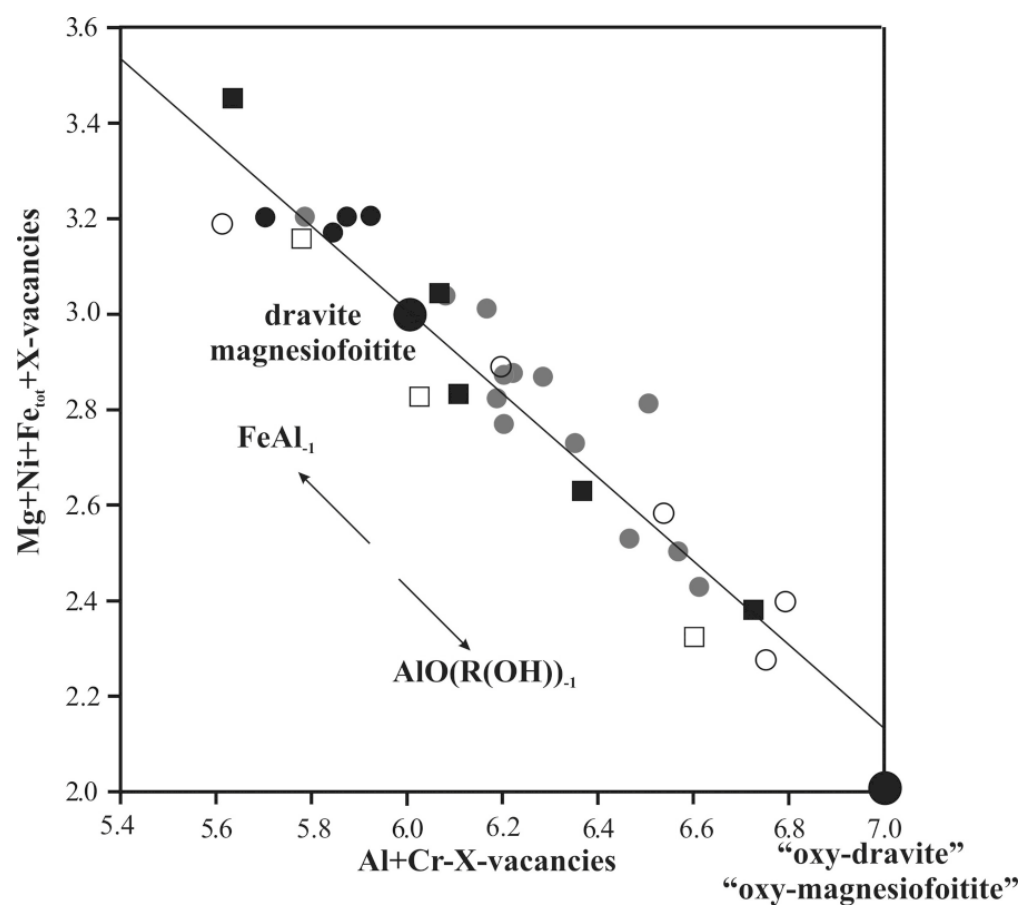

FIg. 10. $\quad(\mathrm{Al}+\mathrm{Cr}-X$-site vacancies $)$ versus $\left(\mathrm{Mg}+\mathrm{Ni}+\mathrm{Fe}_{\text {tot }}+X\right.$-site vacancies $)$ diagram for tourmaline from the nickeloan talc and chromian muscovite associations. $R$ represents the sum of $\mathrm{Fe}$ (total) $+\mathrm{Mg}+\mathrm{Ni}$. The solid line represents a linear least-squares regression through the tourmaline data from both associations, $\left(\mathrm{Mg}+\mathrm{Ni}+\mathrm{Fe}_{\text {tot }}+X\right.$-site vacancy $)=-0.873(\mathrm{Al}+\mathrm{Cr})+8.262$. The directions of several selected exchange-vectors are given for reference. The locations of end-member dravite and magnesiofoitite and "oxy-dravite" and "oxy-magnesiofoitite" are shown by the large filled circles. See Figure 4 for legend.

BORNEMAN-STARYNKEVICH, I.D. (1964): Handbook for Calculating Mineral Formulae. Nauka, Moscow, Russia (in Russ.).

Borodaevsky, N.I. \& BorodaevsKaya, M.B. (1947): The Berezovskoe Ore Field. Metallurgizdat, Moscow, Russia (in Russ.).

Challis, A., Grapes, R. \& Palmer, K. (1995): Chromian muscovite, uvarovite and zincian chromite: products of regional metasomatism in Northwest Nelson, New Zealand. Can. Mineral. 33, 1263-1284.

Dutrow, B.L. \& HENRY, D.J. (2000): Complexly zoned fibrous tourmaline, Cruzeiro mine, Minas Gerais, Brazil: a record of evolving magmatic and hydrothermal fluids. Can. Mineral. 38, 131-143.

Gourdant, J.-P. \& RoBerT, J.-L. (1997): The Mg-Ni substitution in synthetic tourmalines: crystal-chemical considerations in the system $\mathrm{Na}_{2} \mathrm{O}-\mathrm{MgO}-\mathrm{NiO}-\mathrm{Al}_{2} \mathrm{O}_{3}-\mathrm{B}_{2} \mathrm{O}_{3}-\mathrm{SiO}_{2}-$ $\mathrm{H}_{2} \mathrm{O}$. Tourmaline-97, Abstr., 32-33.
Groat, L.A., Marshall, D.D., Giuliani, G., Murthy D.C., PierCEY S.J., JamboR, J.L., MORTENSEN, J.K., ECRIT, T.S., Gault, R.A., Mattey, D.P., Schwarz, D., Maluski, H., Wise, M.A., WengZYNOWSKY, W. \& EATON, D.W. (2002) Mineralogical and geochemical study of the Regal Ridge emerald showing, southeastern Yukon. Can. Mineral. 40, 1313-1338

Hawthorne, F.C. \& HenRy, D.J. (1999): Classification of the minerals of the tourmaline group. Eur. J. Mineral. 11, 201215.

Selway, J.B., Kato, A., Matsubara, S., Shimizu, M., GRICE, J.D. \& VAJDAK, J. (1999): Magnesiofoitite, $\square\left(\mathrm{Mg}_{2} \mathrm{Al}\right) \mathrm{Al}_{6}\left(\mathrm{Si}_{6} \mathrm{O}_{18}\right)\left(\mathrm{BO}_{3}\right)_{3}(\mathrm{OH})_{4}$, a new alkali-deficient tourmaline. Can. Mineral. 37, 1439-1443.

HenRY, D.J. \& Dutrow, B.L. (1996): Metamorphic tourmaline and its petrological applications. In Boron: Mineralogy, Petrology, and Geochemistry (E.S. Grew \& L.M. Amovitz, eds.). Rev. Mineral. 33, 503-588. 


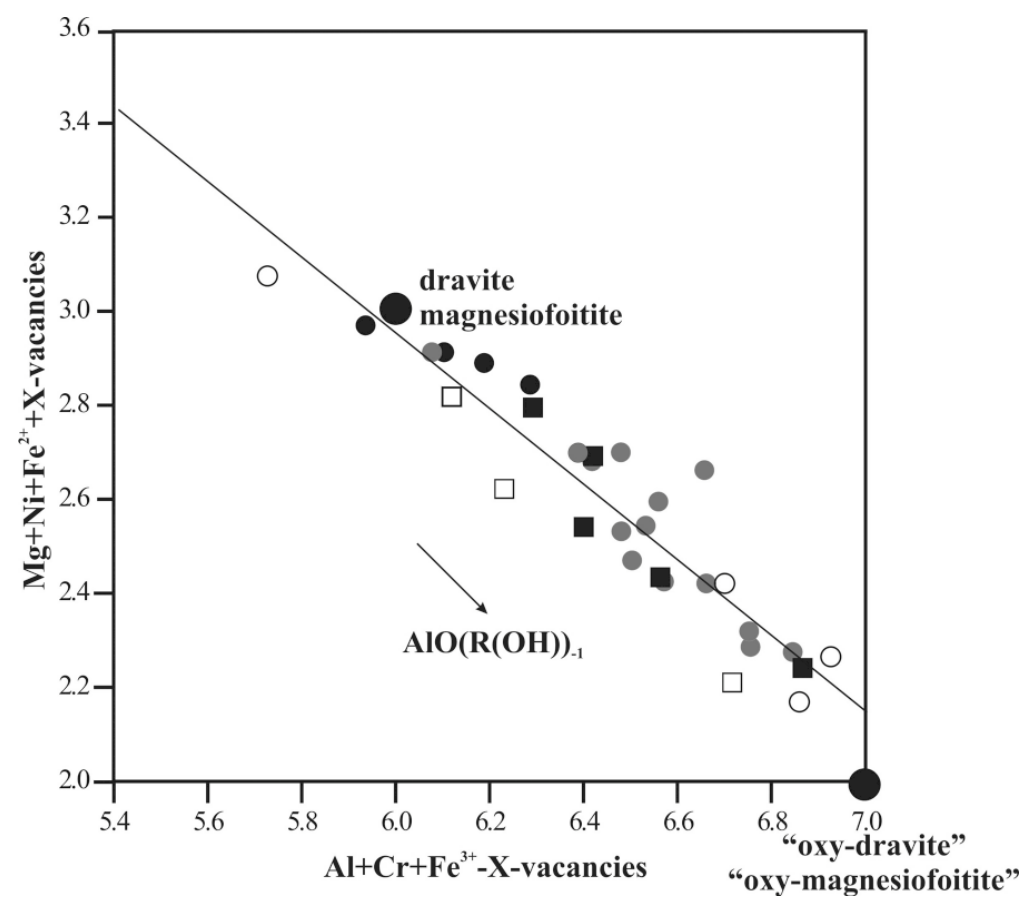

Fig. 11. $\left(\mathrm{Al}+\mathrm{Cr}+\mathrm{Fe}^{3+}-X\right.$-site vacancies $)$ versus $\left(\mathrm{Mg}+\mathrm{Ni}+\mathrm{Fe}^{2+}+X\right.$-site vacancies $)$ diagram for tourmaline from the nickeloan talc and chromian muscovite associations. $R$ represents the sum of $\mathrm{Fe}^{2+}+\mathrm{Mg}+\mathrm{Ni}$. The solid line represents a linear least-squares regression through the tourmaline data from both associations, $\left(\mathrm{Mg}+\mathrm{Ni}+\mathrm{Fe}^{2+}+X\right.$-site vacancy $)=-0.799\left(\mathrm{Al}+\mathrm{Cr}+\mathrm{Fe}^{3+}-X\right.$-site vacancy $)+7.749$. The direction of exchange vector is given for references. The locations of end-member dravite - magnesiofoitite and "oxy-dravite" - "oxy-magnesiofoitite" are shown by the large filled circles. See Figure 4 for legend.

$\&$ (2001): Compositional zoning and element partitioning in nickeloan tourmaline from a metamorphosed karstbauxite from Samos, Greece. Am. Mineral. 86, $1130-1142$.

KIRKLAND, B.L. \& KirKLAND, D.W. (1999): Sector-zoned tourmaline from the cap rock of a salt dome. Eur. J. Mineral. 11, 263-280.

JAN, M.Q., KemPE, D.R.C. \& Symes, R.F. (1972): A chromian tourmaline from Swat, West Pakistan. Mineral. Mag. 38, 756-759.

Jiang, Shao-Yong, Palmer, M.R., Slack, J.F. \& Shaw, D.R. (1998): Paragenesis and chemistry of multistage tourmaline formation in the Sullivan $\mathrm{Pb}-\mathrm{Zn}-\mathrm{Ag}$ deposit, British Columbia. Econ. Geol. 93, 47-67.

KING, R.W., RABIN, O.M. \& FRENCH, D.H. (2000): Tourmaline from Andean porphyry copper deposits: its significance in the exploration of Andean mineralization. CSEG Conf. Abstracts - 2000. http://www.csge.ca/conference/2000/ 307.pdf.
KoRZHINSKII, D.S. (1955): The sketch of metasomatic processes. In Basic Problems in the Theory of Magmatogenic Ore Deposits (A.G. Betekhtin, ed.). Akademia Nauk SSSR, Moscow, Russia (334-456; in Russ.).

Kuzmin, V.I., Dobrovolskaja, N.V. \& Solntseva, L.S. (1979): Tourmaline and its Application for Exploration. Nauka, Moscow, Russia (in Russ.).

London, D. \& Manning, D.A.C. (1995): Chemical variation and significance of tourmaline from southwest England. Econ. Geol. 90, 495-519.

LYNCH, G. \& ORTEGA, S. (1997): Hydrothermal alteration and tourmaline-albite equilibria at the Coxheath porphyry $\mathrm{Cu}-$ Mo-Au deposit, Nova Scotia. Can. Mineral. 35, 79-94.

Medaris, L.G., JR., Fournelle J.H. \& HenRy D.J. (2003): Tourmaline-bearing quartz veins in the Baraboo quartzite, Wisconsin: occurrence and significance of foitite and "oxyfoitite". Can. Mineral. 41, 749-758. 
Michailidis, K., Skavounos, S. \& Plimer, I. (1995): Chromian dravite from the chromite ores of Vavdos area, Chalkidiki peninsula, northern Greece. Neues Jahrb. Mineral., Monatsh., 513-528.

Qivx Inc. Integral Scientist Periodic Table (2003): http:// www.qivx.com/ispt/elements

Robert, F. \& Brown, A.C. (1986): Archean gold-bearing quartz veins at the Sigma mine, Abitibi greenstone belt, Quebec. I. Geologic relations and formation of the vein system. Econ. Geol. 81, 578-617.

Rossovsky, L.N. (1963): Pegmatite hosted in magnesite marble from the gem spinel Kuhilal deposit. Proc. Mineral. Museum 14, 166-181 (in Russ.).

SAzonov, V.N. (1975): Listwaenitization and Mineralization. Nauka, Moscow, Russia (in Russ.).

vAN HERK, A.H. \& DE BOORDER, H. (2001): Spatial and temporal distribution of gold deposits in the Urals. Econ. Geol. 96, 685-703.

SLACK, J.F. (1996): Tourmaline associations with hydrothermal ore deposits. In Boron: Mineralogy, Petrology, and Geochemistry (E.S. Grew \& L.M. Anovitz, eds.). Rev. Mineral. 33, 559-643.

Spiridonov, E.M., Baksheev I.A., Seredkin, M.V., Prokofiev, V.Yu., Ustinov, V.I. \& Filimonov, S.V.
(1998): Gumbeites and associated ore mineralization of the Urals. Geol. Ore Deposits 40, 171-192.

Sustavov, S.G. (1995): The Berezovskoe deposit. Proc. Summer Urals Mineralogical School (Ekaterinburg), 155-164 (in Russ.).

TAYLOR, B.E. \& SLACK, J.F. (1984): Tourmalines from Appalachian-Caledonian massive sulfide deposits: textural, chemical, and isotopic relationships. Econ. Geol. 79, 17031726.

Vikentieva, O.V. (2000): The Berezovskoe Gold Deposit in the Urals: Geological Structure, Mineralogical and Geochemical Features, and Conditions of Formation. Ph.D. thesis, Lomonosov Moscow State Univ., Moscow, Russia (in Russ.).

Vlasov, K.A. \& Kutukova, E.I. (1960): The Emerald Mines. Akad. Nauk SSSR, Moscow, Russia (in Russ.).

YavuZ, F., Iskenderoğlu, A. \& JiAnG, Shao-Yong (1999): Tourmaline compositions from the Salikvan porphyry $\mathrm{Cu}-$ Mo deposit and vicinity, northeastern Turkey. Can. Mineral. 37, 1007-1024.

Received July 26, 2003, revised manuscript accepted July 20, 2004 